\title{
Effects of Lactobacillus buchneri inoculation or 1-propanol supplementation to corn silage on the performance of lactating Holstein cows
}

\section{Janielen da Silva ${ }^{1}$, João Pedro Pereira Winckler ${ }^{1}$, Maximiliano Henrique de Oliveira Pasetti ${ }^{1}$, Pedro Augusto Ribeiro Salvo ${ }^{1}$, Niels Bastian Kristensen ${ }^{2}$, João Luiz Pratti Daniel ${ }^{3^{\star}}$, Luiz Gustavo Nussio 4}

\author{
1 Universidade de São Paulo, Escola Superior de Agricultura "Luiz de Queiroz", Programa de Pós-graduação em Ciência Animal e Pastagens, \\ Piracicaba, SP, Brazil. \\ ${ }^{2}$ SEGES PS, Aarhus, Denmark. \\ ${ }^{3}$ Universidade Estadual de Maringá, Departamento de Zootecnia, Maringá, PR, Brazil. \\ ${ }^{4}$ Universidade de São Paulo, Escola Superior de Agricultura "Luiz de Queiroz", Departamento de Zootecnia, Piracicaba, SP, Brazil.
}

\begin{abstract}
The objective was to evaluate the effects of corn silage supplemented with 1-propanol or inoculated with L. buchneri on the ruminal fermentation profile, digestibility, and production traits of lactating Holstein cows. Whole-corn plants were harvested at $350 \mathrm{~g} / \mathrm{kg}$ dry matter (DM) and packed in nine bag silos (13 t/silo). At ensiling, two treatments were applied: control (no additive; six silos) and L. buchneri inoculation with $1 \times 10^{5} \mathrm{cfu} / \mathrm{g}$ (three silos). Feeding started after 247 days of storage; one L. buchneri and two control silos were opened in each experimental period. Twenty-one multiparous Holstein cows $(\sim 33 \mathrm{~kg} /$ day of milk) were allocated to seven balanced $3 \times 3$ Latin squares with 21-day periods (14 days of adaptation). The experimental diets contained (DM basis): $80 \mathrm{~g} / \mathrm{kg}$ cottonseed, $95 \mathrm{~g} / \mathrm{kg}$ citrus pulp, $180 \mathrm{~g} / \mathrm{kg}$ soybean meal, $90 \mathrm{~g} / \mathrm{kg}$ corn grain (ground), $25 \mathrm{~g} / \mathrm{kg}$ minerals and vitamins premix, and $530 \mathrm{~g} / \mathrm{kg}$ of corn silage. Source of corn silage was the only difference between experimental treatments: control, L. buchneri, or control silage supplemented with 1-propanol (10 g/kg of diet DM). The 1-propanol was dissolved in water (1:1) and sprinkled onto the ration during mixing, immediately before each feeding. Dry matter intake, nutrient digestibility, milk yield, and composition were not affected by treatments. Cows fed 1-propanol had greater concentrations of 1-propanol in the rumen fluid, higher concentration of glucose, and lower concentration of non-esterified fatty acids in blood plasma. Corn silage inoculated with L. buchneri at $1 \times 10^{5} \mathrm{cfu} / \mathrm{g}$ does not affect silage fermentation, ruminal fermentation profile, or milk production. Supplementation of 1-propanol at $10 \mathrm{~g} / \mathrm{kg}$ affects the ruminal fermentation profile without affecting feed intake and milk production of mid-lactating dairy cows.
\end{abstract}

Key Words: aerobic stability, alcohol, heterofermentative inoculant, voluntary feed intake

\section{Introduction}

Whole crop corn is an easy forage to ensile and efficiently preserved under anaerobic conditions, whereas corn silage is highly prone to deterioration upon air exposure. The low aerobic stability is associated with high content of lactic acid and soluble sugars and low concentration of fermentation-end products with antifungal capability (Muck, 2010).

Received: November 13, 2016

Accepted: January 30, 2017

*Corresponding author: jlpdaniel@uem.br

http://dx.doi.org/10.1590/S1806-92902017000700006

How to cite: Silva, J.; Winckler, J. P. P.; Pasetti, M. H. O.; Salvo, P. A. R. Kristensen, N. B.; Daniel, J. L. P. and Nussio, L. G. 2017. Effects of Lactobacillus buchneri inoculation or 1-propanol supplementation to corn silage on the performance of lactating Holstein cows. Revista Brasileira de Zootecnia 46(7):591-598.

Copyright (C) 2017 Sociedade Brasileira de Zootecnia. This is an Open Access article distributed under the terms of the Creative Commons Attribution License (http://creativecommons.org/licenses/by/4.0/), which permits unrestricted use, distribution, and reproduction in any medium, provided the original work is properly cited.
Heterofermentative bacteria, such as Lactobacillus buchneri, have been studied to improve the aerobic stability of corn silages, because they synthetize significant amounts of acetic acid (Kleinschmit and Kung, 2006). Besides acetic acid, the metabolism of lactic acid by L. buchneri also produces 1,2-propanediol (Oude Elferink et al., 2001), which can be further converted to 1-propanol and propionic acid by Lactobacillus diolivorans (Krooneman et al., 2002). Both acetic acid and propionic acid have antifungal action (Moon, 1983) and, therefore, can be effective to improve the aerobic stability of silages.

It is commonly observed that silages with heterofermentative fermentation patterns have more complex headspace-profiles than silages dominated by lactic acid fermentation (Kristensen et al., 2010), leading to an intense debate among researchers and field consultants on the possible negative effects of silages with high concentrations of volatile compounds (e.g., alcohols and esters) on the performance of dairy cows (Raun and Kristensen, 2010; Weiss et al., 2016). We have recently demonstrated that silages inoculated with high doses 
of L. buchneri depress the dry matter (DM) intake and milk yield of lactating dairy cows (Kleinshmitt et al., 2013). A headspace analysis by gas chromatograph-mass spectrometry indicated that 1-propanol was the major volatile compound in those silages inoculated with L. buchneri (unpublished data) and may be involved with the lower feed intake. A positive correlation between 1-propanol and heterofermentation has been previously reported (Raun and Kristensen, 2010).

Thus, the objective of this study was to investigate the effects of $L$. buchneri inoculation and 1-propanol supplementation on the nutritive value of corn silage for dairy cows.

\section{Material and Methods}

The corn crop (hybrid Agroceres AG 1051) was harvested at $350 \mathrm{~g} / \mathrm{kg}$ of dry matter (DM), using a pull-type machine, without kernel processor, adjusted to a theoretical 8 -mm length of cut. The chopped forage was packed in nine bag silos (1.5 m Ø $\times 14 \mathrm{~m}$ length; Pacifil, Estância Velha, Brazil), each with a capacity of 13 tons. The fresh forage contained (DM basis): $86.4 \mathrm{~g} / \mathrm{kg}$ crude protein (CP), $519 \mathrm{~g} / \mathrm{kg}$ of neutral detergent fiber (NDF), $34.7 \mathrm{~g} / \mathrm{kg}$ ether extract (EE), $44.4 \mathrm{~g} / \mathrm{kg}$ ash, $316 \mathrm{~g} / \mathrm{kg}$ non-fiber carbohydrates (NFC), and $72 \mathrm{~g} / \mathrm{kg}$ ethanol-soluble carbohydrates.

Two treatments were imposed at ensiling: control (no additive; six silos) and L. buchneri at $1 \times 10^{5} \mathrm{cfu} / \mathrm{g}$ (three silos). The microbial inoculant (L. buchneri CNCM I - 4323, Lallemand Animal Nutrition, Aparecida de Goiânia, Brazil) was diluted in distilled water $(4 \mathrm{~L} / \mathrm{t})$ and sprayed onto the forage during packing. The same amount of water was added to the control silos.

Two control silos and one inoculated silo were opened in each experimental period of the lactation trial, starting after 247 days of ensiling. Silages were manually fed out from the silos, twice daily, immediately before feeding. Silages from the two control silos were homogenized and divided into two piles. One was used to compose the control diet and the second to compose the diet supplemented with 1-propanol. The number of control silos was the double of L. buchneri silos to keep the same feedout rate.

Silo working face (panel) was evaluated once in each sampling period of the lactation trial. After silage feedout in the morning, silage temperature was measured using bulb thermometers in five points distributed across the silo working face. The thermometers were positioned perpendicular to the silo panel at $10 \mathrm{~cm}$ deep.

Additionally, silage samples were collected for preparing aqueous extracts (1:10) using a stomacher homogenization for $4 \mathrm{~min}$. The $\mathrm{pH}$ of the silage extract was evaluated using a digital pH meter (DM20, Digmed, São Paulo, Brazil). After filtering, the extract was centrifuged for $15 \mathrm{~min}$ at $10,000 \times g$ and the supernatant was frozen at $-20{ }^{\circ} \mathrm{C}$ for later analysis of fermentation end-products. Analyses of acetone, esters, alcohols, and volatile fatty acids were performed using a gas chromatograph with a mass detector (GC-MS) (GCMS QP 2010 plus, Shimadzu, Kyoto, Japan) using a capillary column (Stabilwax, Restek, Bellefonte, USA, $60 \mathrm{~m}, 0.25 \mathrm{~mm} \varnothing, 0.25 \mu \mathrm{m}$ crossbond carbowax polyethlylene glycol) and analytical parameters according to the manufacturer's recommendation. Lactic acid concentration was determined by the colorimetric method proposed by Pryce (1969). The content of ammonia nitrogen $\left(\mathrm{NH}_{3}-\mathrm{N}\right)$ was determined by colorimetry according to Chaney and Marbach (1962). The concentration of ethanol-soluble carbohydrates was analyzed in alcoholic extract by colorimetry using the phenol-sulfuric method (Hall, 2000).

Silage extracts were further diluted $\left(10^{-2}\right.$ to $\left.10^{-6}\right)$ in Ringer's solution for microbial counts by pour plating in Petri dishes using selective media. Malt extract agar (Himedia, Mumbai, India) was used for enumeration of yeasts and molds after 48 and $72 \mathrm{~h}$ of incubation at $30^{\circ} \mathrm{C}$. Lactic acid bacteria (LAB) were enumerated using de Man, Rogosa, and Sharpe agar (Acumedia, Lansing, USA) after $48 \mathrm{~h}$ of incubation at $30^{\circ} \mathrm{C}$. Plaques with more than 20 and less than 300 colonies were selected and the number of colony forming units (cfu) was expressed in $\log _{10}$.

An aerobic stability test was performed in a room with controlled temperature $\left(25 \pm 1{ }^{\circ} \mathrm{C}\right)$. Samples of $3 \mathrm{~kg}$ of each silage (control and L. buchneri) were loosely allocated in plastic buckets. A temperature sensor (Novus, Porto Alegre, Brazil) was placed at the geometric center of each bucket for recording the temperature every $30 \mathrm{~min}$. The aerobic stability was defined as the time required for raising the silage temperature $2{ }^{\circ} \mathrm{C}$ above the ambient temperature (Moran et al., 1996). Additionally, temperature accumulation $\left({ }^{\circ} \mathrm{C}\right)$ at five and ten days of exposure were computed as an indicator of aerobic deterioration (O'Kiely, 1993). For all silage variables, data from the two control silos were grouped and considered as an average value for each evaluation.

Twenty-one multiparous Holstein cows $(\mathrm{BW}=$ $663 \pm 100 \mathrm{~kg}$ ) with an average of 230 days in milk at the beginning of the experiment, were randomly allocated in seven balanced $3 \times 3$ Latin squares, with 21 -day periods (14 days of adaptation). Animals were housed in a tie-stall barn with a cooling system (micro sprays and fans) and individual feedbunks and water bowls. Cows were milked twice daily at 06:00 and 17:00 h. Animals were cared and 
all procedures performed in compliance with accepted protocols (FASS, 2010).

Experimental diets contained (DM basis) $8 \mathrm{~g} / \mathrm{kg}$ cottonseed, $95 \mathrm{~g} / \mathrm{kg}$ citrus pulp, $180 \mathrm{~g} / \mathrm{kg}$ soybean meal, $90 \mathrm{~g} / \mathrm{kg}$ dry ground corn, $25 \mathrm{~g} / \mathrm{kg}$ minerals + vitamins premix, and $530 \mathrm{~g} / \mathrm{kg}$ of corn silage (control or inoculated with L. buchneri or control added with 1-propanol). The 1-propanol was dissolved in water (1:1) and sprinkled onto the total ration during mixing before each feeding to achieve a concentration of $10 \mathrm{~g} / \mathrm{kg}$ of diet DM. Silages and concentrates were mixed by a self-propelled wagon (Data Ranger, American Calan, Northwood, USA) for $15 \mathrm{~min}$. Diets were offered twice daily at 7:00 and 18:00 $\mathrm{h}$ and the amount of feed was adjusted daily to allow $100 \mathrm{~g} / \mathrm{kg}$ of orts (as fed basis).

The voluntary dry matter intake (DMI) and milk production were recorded between day 15 and day 21 of each period. Milk samples were collected in four milking sections for analyses of protein, fat, lactose, total solids, and milk urea nitrogen (MUN) by infrared spectrometry (MilkoScan FT + 6000), and somatic cell count (SCC) by flow cytometry (Fossomatic 400; Clínica do Leite, Piracicaba, Brazil). Final concentrations of milk components were calculated after adjustment for milk production in each milking. Milk energy excretion $\left(\mathrm{NE}_{\mathrm{L}}\right.$, $\mathrm{Mcal} /$ day) was estimated by multiplying milk yield $(\mathrm{kg} / \mathrm{d})$ by the milk energy content (Mcal $/ \mathrm{kg}$ ), calculated as 0.00929 $\times$ fat $(\mathrm{g} / \mathrm{kg})+0.00547 \times$ protein $(\mathrm{g} / \mathrm{kg})+0.00395 \times$ lactose $(\mathrm{g} / \mathrm{kg})(\mathrm{NRC}, 2001)$.

Chewing behavior was recorded on day 15 by visual observation of the animals throughout a 24-h period to evaluate the possible negative effects of silage fermentation end-products on the eating patterns. Eating and ruminating activities were recorded at 10-min intervals and the 24-h pattern was estimated assuming a constant ingestive behavior between the observations (Maekawa et al., 2002). Chewing was computed as eating + ruminating. Samples of silages, total mixed rations, and orts were also collected to determine the particle size using the Penn State Particle Size Separator (Lammers et al., 1996). Sorting index was determined based on the observed intake of each particle size fraction expressed as a proportion of the predicted intake $(\mathrm{g} / \mathrm{kg}$ as fed). Values $<1000 \mathrm{~g} / \mathrm{kg}$ indicate selective refusal, values $>1000 \mathrm{~g} / \mathrm{kg}$ indicate preferential intake, and values equal to $1000 \mathrm{~g} / \mathrm{kg}$ indicate no sorting (Leonardi and Armentano, 2003).

Blood samples were obtained from coccygeal vessels on day 18 of each period, $2 \mathrm{~h}$ after the morning feeding. Blood was collected in vacuum tubes containing EDTA + sodium fluoride. Plasma was separated by centrifugation
$(2.000 \times g$ for $20 \mathrm{~min})$ and analyzed for glucose (enzymatic kit Glucose HK Liquiform, Labtest Diagnóstica S.A., Lagoa Santa, Brazil) and non-esterified fatty acids (NEFA) (kit Wako, NEFA C, kit no. 994-75409E, Richmond, USA).

Apparent total tract digestibility was determined using indigestible NDF (iNDF) as internal marker. Fecal samples were collected from day 16 to day 20 and composited by cow in each period. Samples of individual ingredients and dried feces were incubated for $288 \mathrm{~h}$ in the rumen of a cannulated cow receiving the control diet (Huhtanen et al., 1994). Cows were weighed on the first day of each period and at the end of the trial. Energy requirement for maintenance $\left(\mathrm{NE}_{\mathrm{L}}\right.$ maintenance, Mcal/day) was calculated in each period as $0.08 \times$ average $\mathrm{BW}^{0.75}$ (NRC, 2001)

Ruminal fluid was sampled through a flexible esophageal tube connected to a vacuum pump on the last day of the experiment (only in the last period), $2 \mathrm{~h}$ after the evening feeding. Samples of approximately $200 \mathrm{~mL}$ were used for measuring $\mathrm{pH}$ and frozen at $-20{ }^{\circ} \mathrm{C}$ for analysis of acetate, propionate, butyrate, 1-propanol, and 1,2-propanediol by GC-MS, as described by silage fermentation end-products.

Samples of silages, concentrates, and orts were dried in a forced-ventilation oven at $55{ }^{\circ} \mathrm{C}$ for $72 \mathrm{~h}$ and ground through a 1-mm screen (Wiley mill). The concentrations of DM (method number 930.15), ash (method number 924.05), and EE (method number 920.39) were determined according to the AOAC (1990). The DM was corrected for volatile compounds according to Weissbach (2009). The concentration of $\mathrm{CP}$ was determined by combustion according to the method described by Wiles et al. (1998). The content of NDF was determined with an ANKOM $^{\circledR}$ Fiber Analyzer (ANKOM Technology Corporation, Fairport, USA) using amylase and sodium sulfite (Mertens, 2002). The content of organic matter (OM) was calculated by discounting the ash content of the DM content. The NFC was calculated as $100-$ ash $-\mathrm{CP}-\mathrm{NDF}-\mathrm{EE}$ (NRC, 2001).

Data of animal performance were analyzed using the Mixed procedure of SAS (Statistical Analysis System, version 9.3). The final model included the fixed effects of treatment and period and random effect of cow. The fixed effect of treatment $\times$ period was initially tested, but dropped from the model, since it was not significant. Autoregressive order 1 was used as the covariance structure and cow was the subject (Tempelman, 2004). Means were compared by the Tukey-Kramer test ( $\alpha=0.05$ and $\alpha=0.10$ ). The concentrations of ruminal fermentation products were compared considering the random effect of Latin square and the fixed effect of treatment. The composition of the silages was analyzed using a model that included fixed effects of treatment and random effect of period. 


\section{Results}

The LAB count was greater in L. buchneri silage, whereas the remaining variables were not affected by treatments, including the concentrations of fermentation products and aerobic stability (Table 1). Therefore, the compositions of the experimental diets were similar (Table 2).

No changes were observed in feeding behavior and DMI of cows fed silage inoculated with L. buchneri or supplemented with 1-propanol. In general, animals preferred shorter particles $(<19 \mathrm{~mm})$, but cows fed L. buchneri showed less preference for long particles $(>19 \mathrm{~mm})$ in favor of finer particles $(<8 \mathrm{~mm})$. Nonetheless, there were no differences in milk yield and milk composition across treatments (Tables 3 and 4).

Apparent digestibility of nutrients and energy partitioning were not affected by treatments, but diet $\mathrm{NE}_{\mathrm{L}}$ was numerically lower for L. buchneri. Therefore, cows fed

Table 1 - Composition and management traits of experimental corn silages $(\mathrm{g} / \mathrm{kg} \mathrm{DM}$, unless otherwise stated)

\begin{tabular}{|c|c|c|c|c|}
\hline \multirow{2}{*}{ Item $^{1}$} & \multicolumn{2}{|c|}{ Treatment $^{2}$} & \multirow{2}{*}{ SEM } & \multirow{2}{*}{ P-value } \\
\hline & Control & L. buchneri & & \\
\hline Dry matter (g/kg as fed) & 353 & 355 & 0.8 & 0.63 \\
\hline Ethanol soluble carbohydrates & 32.9 & 26.3 & 0.23 & 0.13 \\
\hline $\mathrm{N}-\mathrm{NH}_{3}(\mathrm{~g} / \mathrm{kg} \mathrm{N})$ & 84.4 & 75.4 & 0.32 & 0.14 \\
\hline $\mathrm{pH}$ & 3.85 & 3.80 & 0.04 & 0.46 \\
\hline Lactic acid & 32.7 & 33.3 & 0.52 & 0.91 \\
\hline Acetic acid & 13.0 & 13.8 & 0.40 & 0.54 \\
\hline Propionic acid & 8.87 & 8.99 & 0.23 & 0.86 \\
\hline 1,2-propanediol & 6.88 & 7.80 & 0.19 & 0.69 \\
\hline Butyric acid & 3.91 & 3.99 & 0.14 & 0.86 \\
\hline Ethanol & 3.50 & 4.99 & 0.09 & 0.34 \\
\hline 2,3-Butanediol & 1.24 & 0.92 & 0.10 & 0.34 \\
\hline 1-propanol & 0.67 & 1.01 & 0.03 & 0.38 \\
\hline Valeric acid (mg/kg DM) & 652 & 657 & 128 & 0.93 \\
\hline i-Valeric acid (mg/kg DM) & 491 & 492 & 85 & 0.98 \\
\hline i-Propyl alcohol (mg/kg DM) & 36 & 49 & 15 & 0.65 \\
\hline Ethyl lactate (mg/kg DM) & 23 & 38 & 10 & 0.21 \\
\hline Ethyl acetate (mg/kg DM) & 12 & 32 & 7 & 0.14 \\
\hline 2-Butanol (mg/kg DM) & 5 & 11 & 4 & 0.14 \\
\hline Propyl acetate (mg/kg DM) & 2 & 6 & 1 & 0.14 \\
\hline $\begin{array}{l}\text { Lactic acid bacteria } \\
(\log \mathrm{cfu} / \mathrm{g} \text { as fed })\end{array}$ & 5.89 & 6.33 & 0.06 & 0.02 \\
\hline Yeast (log cfu/g as fed) & 3.38 & 3.39 & 0.04 & 0.83 \\
\hline Mold (log cfu/g as fed) & 2.74 & 2.35 & 0.39 & 0.55 \\
\hline Removal rate (m/day) & 0.430 & 0.403 & 0.052 & 0.18 \\
\hline Density ( $\mathrm{kg}$ as fed/m³) & 422 & 391 & 14.4 & 0.23 \\
\hline Silo face temperature $\left({ }^{\circ} \mathrm{C}\right)$ & 29.3 & 28.9 & 0.17 & 0.21 \\
\hline Aerobic stability (h) & 15.8 & 24.5 & 3.35 & 0.12 \\
\hline $\begin{array}{l}\text { Accumulated temperature } \\
\left(\text { day } 5 ;{ }^{\circ} \mathrm{C}\right)\end{array}$ & 64.1 & 54.8 & 5.47 & 0.35 \\
\hline $\begin{array}{l}\text { Accumulated temperature } \\
\left(\text { day } 10 ;{ }^{\circ} \mathrm{C}\right)\end{array}$ & 113 & 106 & 3.3 & 0.21 \\
\hline
\end{tabular}

SEM - standard error of the mean.

${ }^{1}$ Dry matter (DM) corrected for volatile compounds.

${ }^{2}$ Control - no additive; L. buchneri - inoculated with L. buchneri at $1 \times 10^{5} \mathrm{cfu} / \mathrm{g}$.
L. buchneri tended to have lower energy balance (Table 5). Proportions of major rumen volatile fatty acids were not modified by diets. In contrast, 1-propanol was increased in the rumen of cows fed the 1-propanol diet. Similarly, blood glucose concentration tended to be higher and NEFA concentration was lower for the 1-propanol treatment (Table 6).

\section{Discussion}

Lactobacillus buchneri is a heterolactic bacterium used to improve the aerobic stability of silages. However, there are still questions about the potentially adverse effects of fermentation products found in silages inoculated with it on feed intake, metabolism, and animal performance.

Table 2 - Chemical composition of the experimental diets consumed by the animals ( $\mathrm{g} / \mathrm{kg}$ dry matter, unless otherwise stated)

\begin{tabular}{lccc}
\hline \multirow{2}{*}{ Item } & \multicolumn{3}{c}{ Treatment $^{1}$} \\
\cline { 2 - 4 } & Control & L. buchneri & 1-propanol \\
\hline DM (g/kg as fed) & 433 & 432 & 438 \\
CP & 178 & 177 & 176 \\
NDF & 322 & 337 & 319 \\
iNDF & 141 & 147 & 140 \\
EE & 42.5 & 42.9 & 42.1 \\
Ash & 53.8 & 56.6 & 53.2 \\
NFC & 404 & 386 & 410 \\
\hline
\end{tabular}

DM - dry matter corrected for volatile compounds; CP - crude protein; NDF neutral detergent fiber; iNDF - indigestible NDF; EE - ether extract; NFC - non-fiber carbohydrates.

${ }^{1}$ Control - no additive; L. buchneri - inoculated with L. buchneri at $1 \times 10^{5} \mathrm{cfu} / \mathrm{g}$; 1 -propanol - supplemented with 1-propanol at $10 \mathrm{~g} / \mathrm{kg}$ dry matter.

Table 3 - Performance of dairy cows fed diets with corn silage inoculated with L. buchneri or supplemented with 1-propanol

\begin{tabular}{lccccc}
\hline \multirow{2}{*}{ Item } & \multicolumn{4}{c}{ Treatment $^{1}$} & \\
\cline { 2 - 4 } & Control & L. buchneri & 1-propanol & & \\
\hline DMI (kg/day) & 20.9 & 20.5 & 20.0 & 0.50 & 0.26 \\
Milk yield (kg/day) & 32.1 & 31.3 & 31.3 & 1.45 & 0.35 \\
FCM (kg/day) & 32.0 & 31.3 & 31.4 & 1.55 & 0.74 \\
Fat (g/kg) & 35.3 & 35.1 & 36.0 & 0.10 & 0.72 \\
Fat $(\mathrm{kg})$ & 1.12 & 1.10 & 1.11 & 0.06 & 0.86 \\
Protein $(\mathrm{g} / \mathrm{kg})$ & 33.8 & 33.3 & 33.9 & 0.11 & 0.92 \\
Protein $(\mathrm{kg})$ & 1.08 & 1.03 & 1.06 & 0.05 & 0.65 \\
Casein $(\mathrm{g} / \mathrm{kg})$ & 27.0 & 25.5 & 26.0 & 0.10 & 0.60 \\
Lactose $(\mathrm{g} / \mathrm{kg})$ & 45.8 & 45.9 & 45.1 & 0.05 & 0.34 \\
SCC (×1000/mL) & 174 & 107 & 220 & 36.2 & 0.12 \\
MUN (mg/dL) & 11.5 & 12.2 & 12.2 & 0.50 & 0.43 \\
FFA (mmol/10 L) & 2.19 & 1.85 & 1.52 & 0.27 & 0.19 \\
NE milk (Mcal/kg) & 0.691 & 0.688 & 0.687 & 0.013 & 0.96 \\
\hline
\end{tabular}

DMI - dry matter intake; FCM - fat corrected milk ( $35 \mathrm{~g} / \mathrm{kg}$ of fat); SCC - somatic cell count; MUN - milk urea nitrogen; FFA - free fatty acids; $\mathrm{NE}_{\mathrm{L}}$ milk - milk energy; SEM - standard error of the mean.

${ }^{1}$ Control - no additive; L. buchneri - inoculated with L. buchneri at $1 \times 10^{5} \mathrm{cfu} / \mathrm{g}$;

1-propanol - supplemented with 1-propanol at $10 \mathrm{~g} / \mathrm{kg}$ dry matter. 
Table 4 - Feeding behavior of dairy cows fed diets with corn silage inoculated with L. buchneri or supplemented with 1-propanol

\begin{tabular}{|c|c|c|c|c|c|}
\hline \multirow{2}{*}{ Item } & \multicolumn{3}{|c|}{ Treatment $^{1}$} & \multirow{2}{*}{ SEM } & \multirow{2}{*}{ P-value } \\
\hline & Control & L. buchneri & 1-propanol & & \\
\hline Eating (min/day) & 177 & 191 & 176 & 12.1 & 0.51 \\
\hline Ruminating (min/day) & 527 & 522 & 507 & 14.9 & 0.45 \\
\hline Chewing (min/day) & 704 & 711 & 679 & 20.5 & 0.32 \\
\hline Chewing/DM intake (min/kg) & 34.8 & 35.7 & 33.9 & 1.55 & 0.39 \\
\hline Chewing/NDF intake (min/kg) & 110 & 110 & 111 & 5.0 & 0.96 \\
\hline \multicolumn{6}{|l|}{ Sorting index } \\
\hline$>19 \mathrm{~mm}(\mathrm{~g} / \mathrm{kg}$ as fed $)$ & $616 a$ & $445 b$ & $691 \mathrm{a}$ & 35.0 & $<0.01$ \\
\hline 8-19 $\mathrm{mm}$ (g/kg as fed) & 981 & 983 & 986 & 2.7 & 0.36 \\
\hline$<8 \mathrm{~mm}(\mathrm{~g} / \mathrm{kg}$ as fed $)$ & $1138 x y$ & $1157 \mathrm{x}$ & $1118 \mathrm{y}$ & 11.8 & 0.08 \\
\hline
\end{tabular}

DM - dry matter corrected for volatiles; NDF - neutral detergent fiber; SEM - standard error of the mean.

${ }^{1}$ Control - no additive; L. buchneri - inoculated with L. buchneri at $1 \times 10^{5} \mathrm{cfu} / \mathrm{g} ; 1$-propanol - supplemented with 1 -propanol at $10 \mathrm{~g} / \mathrm{kg}$ dry matter.

Means followed by different letters within the same row differ from each other by the Tukey-Kramer test at $\alpha=0.05$ (a,b) or $\alpha=0.10$ (x,y).

Table 5 - Digestibility and energy partitioning in dairy cow diets based on corn silage inoculated with L. buchneri or supplemented with 1-propanol



DM - dry matter corrected for volatiles; CP - crude protein, NDF - neutral detergent fiber, NFC - non-fiber carbohydrates, EE - ether extract, TDN - total digestible nutrients, $\mathrm{NE}_{\mathrm{L}}$ - net energy for lactation, BW - body weight.

${ }^{1}$ Control - no additive; L. buchneri - inoculated with L. buchneri at $1 \times 10^{5} \mathrm{cfu} / \mathrm{g} ; 1$-propanol - supplemented with 1 -propanol at $10 \mathrm{~g} / \mathrm{kg}$ dry matter.

${ }^{2}$ Calculated with digestibility data (NRC, 2001).

$\mathrm{x}, \mathrm{y}$ - Means followed by different letters within the same row differ from each other by the Tukey-Kramer test at $\alpha=0.10$.

Table 6 - Ruminal fermentation products $(\mathrm{mol} / 100 \mathrm{~mol})$ and blood metabolites of dairy cows fed diets with corn silage inoculated with L. buchneri or supplemented with 1-propanol

\begin{tabular}{|c|c|c|c|c|c|}
\hline \multirow{2}{*}{ Item } & \multicolumn{3}{|c|}{ Treatment $^{1}$} & \multirow{2}{*}{ SEM } & \multirow{2}{*}{ P-value } \\
\hline & Control & L. buchneri & 1-propanol & & \\
\hline \multicolumn{6}{|c|}{ Ruminal fermentation product } \\
\hline Acetate & 56.2 & 57.6 & 56.8 & 3.46 & 0.96 \\
\hline Propionate & 25.5 & 25.1 & 25.0 & 1.52 & 0.97 \\
\hline Butyrate & 16.4 & 18.1 & 16.0 & 1.36 & 0.55 \\
\hline 1- Propanol & $0.015 b$ & $0.005 b$ & $0.500 \mathrm{a}$ & 0.111 & 0.04 \\
\hline 1,2-Propanediol & 0.163 & 0.113 & 0.140 & 0.027 & 0.48 \\
\hline Acetate:propionate ratio & 2.27 & 2.40 & 2.26 & 0.32 & 0.93 \\
\hline \multicolumn{6}{|l|}{ Blood metabolite } \\
\hline Glucose (mg/dL) & $59.1 \mathrm{y}$ & $59.1 \mathrm{y}$ & $64.3 x$ & 1.93 & 0.08 \\
\hline NEFA (mmol/L) & $0.184 a$ & $0.189 \mathrm{a}$ & $0.157 \mathrm{~b}$ & 0.011 & 0.04 \\
\hline
\end{tabular}

NEFA - non-esterified fatty acids; SEM - standard error of the mean.

${ }^{1}$ Control - no additive; L. buchneri - inoculated with L. buchneri at $1 \times 10^{5} \mathrm{cfu} / \mathrm{g} ; 1$-propanol - supplemented with 1 -propanol at $10 \mathrm{~g} / \mathrm{kg}$ dry matter.

Means followed by different letters within the same row differ from each other by the Tukey-Kramer test at $\alpha=0.05(\mathrm{a}, \mathrm{b})$ or $\alpha=0.10(\mathrm{x}, \mathrm{y})$. 
As reported in the literature, one of the metabolic pathways of $L$. buchneri is the conversion of lactic acid to acetic acid and 1,2-propanediol (Oude Elferink et al., 2001). In addition, 1,2-propanediol can be converted to 1-propanol and propionic acid by Lactobacillus diolivorans (Krooneman et al., 2002). Therefore, silages inoculated with L. buchneri may have high concentrations of acetic acid (Driehuis et al., 1999a; Ranjit and Kung, 2000; Hu et al., 2009), 1,2-propanodiol (Nishino et al., 2002; Driehuis et al., 1999b), propionic acid (Driehuis et al., 1999a; Wu-Tai et al., 2002), and 1-propanol (Driehuis et al., 1999a; Wu-Tai et al., 2002; Kristensen et al., 2010; Li and Nishino, 2011). In the current experiment, the dose of $1 \times 10^{5} \mathrm{cfu} / \mathrm{g}$ was not enough to raise the concentrations of these fermentation products in our silages.

Several studies reported improvements in aerobic stability of silage inoculated with L. buchneri, simultaneously to greater acetic acid concentration and lower yeast population (Ranjit and Kung, 2000; Filya, 2003; Schmidt and Kung, 2010). Therefore, the lack of benefit in aerobic stability for silages inoculated with L. buchneri in the current study might be mainly explained by the lack of response in acetic acid concentration and yeast counts. In Brazil, the typical commercial dose of inoculants containing L. buchneri is $1 \times 10^{5} \mathrm{cfu} / \mathrm{g}$ of forage. However, this low dose may be a plausible explanation for our results, because the changes in parameters such as aerobic stability and accumulated temperatures were mild regarding the control silage. In most studies in which benefits of aerobic stability were found with use of L. buchneri, the application rate was higher than the dose adopted in the present work (Nishino et al., 2004; Muck, 2004; Weinberg et al., 2002; Filya et al., 2006; Hu et al., 2009). In this way, Kleinschmit and Kung (2006) conducted a meta-analysis on the effects of $L$. buchneri on silages. The studies were stratified by crop and application rate in: control (untreated), $1 \times 10^{5} \mathrm{cfu} / \mathrm{g}$, and $>1 \times 10^{5} \mathrm{cfu} / \mathrm{g}$ forage. For corn, silages were compiled over 26 experiments and in most studies, significant responses in aerobic stability were only obtained for inoculation doses greater than $1 \times 10^{5} \mathrm{cfu} / \mathrm{g}$ (Kleinschmit and Kung, 2006), which might support the absence of benefits of L. buchneri in the current trial.

Milk yield was not affected by treatments, probably due to a similarity in DMI and digestibility of nutrients. In the study conducted by Kristensen et al. (2007), there were also no changes in DMI and milk yield of primiparous cows fitted with permanent indwelling catheters in splanchnic tissues and receiving 1-propanol (5.6 $\mathrm{g} / \mathrm{kg}$ of diet DM). Likewise, Raun and Kristensen (2012) supplemented a high dose of 1-propanol (50 g/ $/ \mathrm{kg}$ of diet DM), which is not typical in silages, to challenge multiparous cows fitted with permanent indwelling catheters in splanchnic tissues. They did not observe changes in DMI and milk yield, but reported lower content of milk fat in cows supplemented with 1-propanol.

There are few studies reporting the effects of corn silage inoculation with L. buchneri on the performance of dairy cows. Kristensen et al. (2010) tested a dose of $3 \times 10^{5}$ cfu/g of L. buchneri in corn silage (comprising $390 \mathrm{~g} / \mathrm{kg}$ of diet $\mathrm{DM}$ ) in dairy farms and found no differences in the in vitro DM digestibility and milk yield (30.6 and $31.3 \mathrm{~kg} / \mathrm{d}$ for control and inoculated silage, respectively). Driehuis et al. (1999b) used a dose of $1 \times 10^{5} \mathrm{cfu} / \mathrm{g}$ of L. buchneri in corn silage (comprising $330 \mathrm{~g} / \mathrm{kg}$ of diet DM) for dairy cows, but did not observe differences in DMI, milk yield, or milk composition. In the present experiment, corn silage was the sole forage source and the inclusion in the diets $(530 \mathrm{~g} / \mathrm{kg} \mathrm{DM})$ was higher than those in the referenced studies. Notwithstanding, acetic acid concentration was low and similar across treatments (13.0 and $13.8 \mathrm{~g} / \mathrm{kg}$ for the control and inoculated silages, respectively), with no interference on animal performance. Previous studies reported a clear negative effect of acetic acid on feeding behavior, but the dietary concentrations of acetic acid were higher than those found in the present trial (Dinius et al., 1968; Hutchinson and Wilkins, 1971; Krizsan et al., 2012; Daniel et al., 2013).

Despite similarities in $\mathrm{NE}_{\mathrm{L}}$ utilization for maintenance and milk yield, cows fed silage inoculated with $L$. buchneri showed a lower $\mathrm{NE}_{\mathrm{L}}$ balance. The numerical difference in $\mathrm{BW}$ variation suggests a lower accretion of body reserves in cows fed diet with L. buchneri. Blood glucose concentration was higher in cows fed diets supplemented with 1-propanol. Although the proportions of acetate and propionate in the rumen fluid were not modified across treatments, animals that received 1-propanol showed higher proportions of this alcohol in the rumen. Possibly, 1-propanol was partially recovered in the portal blood and converted to glucose in the liver (Czerkawski et al., 1984; Cozzi et al., 1996). Raun and Kristensen (2012) reported a portal recovery of 48 to $61 \%$ of the 1-propanol intake, with a consequent increase in hepatic uptake of 1-propanol, increased hepatic flow of glucose, and reduction in milk fat content. In the current trial, the improvement in the glucogenic status led to lower mobilization of triglycerides and lower blood concentration of NEFA in animals supplemented with 1-propanol. However, the increased glucogenic status induced by 1-propanol may not have been enough to depress the milk fat content in our mid-lactation cows. 


\section{Conclusions}

Diets containing corn silages inoculated with Lactobacillus buchneri at $1 \times 10^{5} \mathrm{cfu} / \mathrm{g}$ or $10 \mathrm{~g} / \mathrm{kg}$ of 1 -propanol (dry matter basis) do not change the performance of midlactation dairy cows.

\section{References}

AOAC - Association of Official Analytical Chemistry. 1990. Official methods of analysis. 15th ed. AOAC International, Arlington, VA, USA.

Chaney, A. L. and Marbach, E. P. 1962. Modified reagents for determination of urea and ammonia. Clinical Chemistry $8: 130-137$

Cozzi, G.; Berzaghi, P.; Gottardo, F.; Gabai, G. and Andrighetto, I. 1996. Effects of feeding propyleneglycol to mid-lactating dairy cows. Animal Feed Science and Technology 64:43-51.

Czerkawski, J. W.; Piatkova, M. and Breckenbridge, G. 1984. Microbial metabolism of 1,2-propanediol studied by the rumen simulation technique (Rusitec). Journal of Applied Bacteriology 56:81-94.

Daniel, J. L. P.; Amaral, R. C.; Sá Neto, A.; Cabezas-Garcia, E. H.; Bispo, A. W.; Zopollatto, M.; Cardoso, T. L.; Spoto, M. F. F.; Santos, F. A. P. and Nussio, L. G. 2013. Performance of dairy cows fed high levels of acetic acid or ethanol. Journal of Dairy Science 96:398-406.

Dinius, D. A.; Hill, D. L. and Noner, C. H. 1968. Influence of supplemental acetate feeding on the voluntary intake of cattle fed green corn and corn silage. Journal of Dairy Science 51:1505-1507.

Driehuis, F.; Oude Elferink, S. J. W. H. and Spolestra, S. F. 1999a. Anaerobic lactic acid degradation during ensilage of whole crop maize inoculated with Lactobacillus buchneri inhibits yeast growth and improves aerobic stability. Journal of Applied Microbiology 87:583-594.

Driehuis, F.; Oude Elferink, S. J. W. H. and Van Wikleaar, P. G. 1999b. Lactobacillus buchneri improves the aerobic stability of laboratory and farm scale whole crop maize but does not affect feed intake and milk production of dairy cows. p.106-107. In: Proceedings of the 12th International Silage Conference, Swedish University of Agricultural Science, Uppsala, Sweden.

FASS - Federation of Animal Science Societies. 2010. Guide for the care and use of agricultural animals in teaching and research. 3rd ed. Champaign, IL.

Filya, I. 2003. The effect of Lactobacillus buchneri and Lactobacillus plantarum on the fermentation, aerobic stability, and ruminal degradability of low dry matter corn and sorghum silages. Journal of Dairy Science 86:3575-3581.

Filya, I.; Sucu, E. and Karabulut, A. 2006. The effect of Lactobacillus buchneri on the fermentation, aerobic stability and ruminal degradability of maize silage. Journal of Applied Microbiology 101:1216-1223.

Hall, M. B. 2000. Neutral detergent-soluble carbohydrate nutritional relevance and analysis. Bulletin 339. University of Florida, Gainesville, USA.

Hu, W.; Schmidt, R. J.; McDonell, E. E.; Klingerman, C. M. and Kung Jr., L. 2009. The effect of Lactobacillus buchneri 40788 or Lactobacillus plantarum MTD1 on the fermentation and aerobic stability of corn silages ensiled at two dry matter contents. Journal of Dairy Science 92:3907-3914.
Huhtanen, P.; Kaustell, K. and Jaakkola, S. 1994. The use of internal markers to predict total digestibility and duodenal flow of nutrients in cattle given six different diets. Animal Feed Science and Technology 48:211-227.

Hutchinson, K. J. and Wilkins, R.J. 1971. The voluntary intake of silage by sheep. II. The effects of acetate on silage intake. Journal of Agricultural Science 77:539-543.

Kleinschmit, D. H. and Kung Jr., L. 2006. A meta analysis of the effects of Lactobacillus buchneri on the fermentation and aerobic stability de corn and grass and small grain silages. Journal of Dairy Science 89:4005-4013

Kleinshmitt, C.; Morais, G.; Custódio, L.; Fernandes, J.; Santos, M. C.; Daniel, J. L. P. and Nussio, L. G. 2013. Performance of lactating dairy cows fed maize silage with increased dosages of L. buchneri. p.141-142. In: Proceedings of the 15th International Conference on Forage Conservation, High Tatras, Slovakia.

Kristensen, N. B.; Storm, A. B.; Raun, M. L. B.; Røjen, A. and Harmon, D. L. 2007. Metabolism of silage alcohols in lactating dairy cows. Journal of Dairy Science 90:1364-1377.

Kristensen, N. B.; Sloth, K. H.; Højberg, O.; Spliid, N. H.; Jensen, C. and Thøgersen, R. 2010. Effects of microbial inoculants on corn silage fermentation, microbial contents, aerobic stability, and milk production under field conditions. Journal of Dairy Science 93:3764-3774.

Krizsan, S. J.; Randby, A. T. and Westad, F. 2012. Effect of acetic acid, caproic acid and tryptamine on voluntary intake of grass silage by growing cattle. Grass and Forage Science 67:361-368.

Krooneman, J.; Faber, F.; Alderkamp, A.; Oude Elferink, S. J. H. W.; Driehuis, F.; Cleenwerck, I.; Swings, J.; Gottschal, J. and Vancanneyt, M. 2002. Lactobacillus diolivorans sp nov., a 1,2propanediol-degrading bacterium isolated from aerobically stable maize silage. International Journal of Systematic and Evolutionary Microbiology 52:639-646.

Lammers, B. P.; Buchmaster, D. R. and Heinrichs, E. J. 1996. A simple method for the analysis of particle sizes of forage and total mixed rations. Journal of Dairy Science 79:922-928.

Leonardi, C. and Armentano, L. E. 2003. Effect of quantity, quality, and length of alfafa hay on selective consumption by dairy cows. Journal of Dairy Science 86:557-564.

Li, Y. and Nishino, N. 2011. Effects of inoculation of Lactobacillus rhamnosus and Lactobacillus buchneri on fermentation, aerobic stability and microbial communities in whole crop corn silage. Grassland Science 57:184-191.

Maekawa, M.; Beauchemin, K. A. and Christensen, D. A. 2002. Effect of concentrate level and feeding management on chewing activities, saliva production, and ruminal $\mathrm{pH}$ of lactating dairy cows. Journal of Dairy Science 85:1165-1175.

Mertens, D. R. 2002. Gravimetric determination of amylasetreated neutral detergent fibre in feeds with refluxing beakers or crucibles: collaborative study. Journal of AOAC International $85: 1217-1240$

Moon, N. J. 1983. Inhibition of the growth of acid tolerant yeasts by acetate, lactate and propionate and their synergistic mixtures. Journal of Applied Bacteriology 55:453-460.

Moran, J.; Weinberg, Z. G. and Ashbell, G. 1996. A comparison of two methods for the evaluation of the aerobic stability of whole crop wheat silage. p.162-163. In: Proceedings of the 11th International Silage Conference, Alberystwyth, Wales.

Muck, R. E. 2004. Effects of corn silage inoculants on aerobic stability. Transactions of the American Society of Agricultural Engineers 47:1011-1016.

Muck, R. E. 2010. Silage microbiology and its control through additives. Revista Brasileira de Zootecnia 39:183-191.

NRC - National Research Council. 2001. Nutrients requirements of dairy cattle. 7 th ed. Washington, USA. 
Nishino, N.; Yoshida, M.; Shiota, H. and Sakaguchi, E. 2002. Evaluation of Lactobacillus buchneri derived from by-products ensiling as an inoculum for whole crop maize silage. p.146-147. In: Proceedings of the $13^{\text {th }}$ International Silage Conference, Scottish Agricultural College, Auchincruive, Scotland.

Nishino, N.; Yoshida, M.; Shiota, H. and Sakaguchi, E. 2004. Accumulation of 1,2-propanediol and enhancement of aerobic stability in whole crop maize silage inoculated with Lactobacillus buchneri. Journal of Applied Microbiology 94:800-807.

O'Kiely, P. 1993. Influence of a partially neutralised blend of aliphatic organic acids on fermentation, effluent production and aerobic stability of autumn grass silage. Irish Journal of Agricultural and Food Research 32:13-26.

Oude Elferink, S. J. W. H.; Krooneman, J.; Gottschal, J. C.; Spoelstra, S. F.; Faber, F. and Driehuis, F. 2001. Anaerobic conversion of lactic acid to acetic acid and 1,2 propanediol by Lactobacillus buchneri. Applied and Environmental Microbiology 67:125-132.

Pryce, J. D. 1969. A modification of Barker-Summerson method for the determination of lactic acid. Analyst 94:1151-1152.

Ranjit, N. K. and Kung Jr., L. 2000. The effect of Lactobacillus buchneri, Lactobacillus plantarum, or a chemical preservative on the fermentation and aerobic stability of corn silage. Journal of Dairy Science 83:526-535.

Raun, B. M. L. and Kristensen, N. B. 2010. Propanol in maize silage at Danish dairy farms. Acta Agriculturæ Scandinavica 60:53-59.

Raun, B. M. L. and Kristensen, N. B. 2012. Metabolic effects of feeding high doses of propanol and propylacetate to lactating Holstein cows. Livestock Production Science 144:37-47.
Schmidt, R. J. and Kung Jr., L. 2010. The effects of Lactobacillus buchneri with or without a homolactic bacterium on the fermentation and aerobic stability of corn silages made at different locations. Journal of Dairy Science 93:1616-1624.

Tempelman, R. J. 2004. Experimental design and statistical methods for classical and bioequivalence hypothesis testing with an application to dairy nutrition studies. Journal of Animal Science 82:E162-E172.

Weinberg, Z. G.; Ashbell, G.; Hen, Y.; Szakacs, G. and Filya, I. 2002. Ensiling whole-crop wheat and corn in large containers with Lactobacillus plantarum and Lactobacillus buchneri. Journal of Industrial Microbiology and Biotechnology 28:7-11.

Weiss, K.; Kroschewski, B. and Auerbach, H. 2016. Effects of air exposure, temperature and additives on fermentation characteristics, yeast count, aerobic stability and volatile organic compounds in corn silage. Journal of Dairy Science 99:8053-8069.

Weissbach, F. 2009. Correction of dry matter content of silages used as substrate for biogas production. p.483-484. In: Proceedings of the 15th International Silage Conference, US Dairy Forage Research Center, Madison, WI.

Wiles, P. G.; Gray, I. K. and Kissling, R. C. 1998. Routine analysis of protein by Kjeldahl and Dumas methods: review and interlaboratory study using dairy products. Journal of AOAC International 81:620-632.

Wu-Tai, G.; Driehuis, F. and Wikselaar, P. V. 2002. The influences of addition of sugar with or without L. buchneri on fermentation and aerobic stability of whole crop maize silage ensiled under anaerobic silos. Asian-Australasian Journal of Animal Sciences $15: 1128-1133$ 